\title{
A Study of the Facial Flatness in Several Cranial Series from East Asia and North America
}

\author{
Yukio DODO \\ Department of Anatomy, Sapporo Medical College
}

\begin{abstract}
Three sets of facial flatness measurements were taken of five Mongoloid cranial series from North America, and two Mongoloid and one Caucasoid cranial series from East Asia. The data of the Ainu and Japanese quoted from YAMAGUCHI (1973) were also used as a comparison. The definitions of measurements and indices of flatness were the same as described by YAMAGUCHI (1.c.). Correlation between sexes measured by the SPEARMAN rank correlation coefficient was considerably high in each of the frontal, simotic, and zygomaxillary indices. High correlation between the two sexes was also observed in PENROSE shape distances based on the three sets of measurements. From three-dimensional diagrams of the three indices of flatness, it was inferred that the combination of frontal and zygomaxillary indices was more effective than that of the frontal and simotic indices in differentiating Mongoloid and Caucasoid groupings from each other. The principal co-ordinates analyses on the basis of the matrix of PENROSE shape distances showed that, though they were within the range of variation of the Mongoloid series, the Japanese and Ontario Iroquois formed a cluster, as did the Canadian Eskimos and Inupik-speaking Alaskan Eskimos. In regard to the facial flattening, the Ainu was far closer to the Mongoloid series than to the Caucasoid series. It was confirmed that the Eskimo's face was characterized by extremely flat frontal and zygomaxillary regions and pronounced nasal bones. The causation of the reduced but prominent, or "pinched", nasal bones of the Eskimos was briefly discussed.
\end{abstract}

Keywords Facial flatness measurements, Mongoloids, East Asia, North America

\section{Introduction}

Four sets of measurements of the transverse facial flatness of the human cranium were formulated and applied to a large number of crania from the greater part of the world by Woo and MoRant (1934). As a result, they found that two of their indices, the simotic and frontal indices, were particularly effective in discriminating

Article No. 8533 Received October 4, 1985. 
the racial varieties of modern man. Russian anthropologists, defining the zygomaxillary measurements and index in place of the premaxillary ones proposed by Woo and MORANT (1. c.), gave numerical data on the facial flatness of the cranium in Siberian Mongoloid populations (DEBETS, 1951 ; ALEXSEEV, 1979a). They concluded that these measurements were not only effective in discriminating Mongoloid crania from Europoid crania, but also useful in distinguishing among local Mongoloid variants.

Applying the new series of measurements to the Ainu, Japanese and Jomon crania, YAMAGUCHI $(1973,1980)$ disclosed their positions in relation to the adjacent populations from the standpoint of facial flattening.

In North America, these flatness measurements had been considered as an excellent indicator in distinguishing Eskimo crania from American Indian crania (OschINSKY, 1962, 1964). Recently, AlEKSEYEV (1979b) stressed that the horizontal facial profile is of great taxonomic significance for the differentiation of the Arctic Mongoloid and American Indian populations, though considerable overlappings of mean values were observed between these two groupings (HeATHCOTE, 1981).

A major objective of the present study is to examine the variation of facial flatness in the Mongoloid crania from East Asia and North America by means of a recently developed statistical analysis.

\section{Materials}

Facial flatness measurements were taken of five Mongoloid cranial series from North America, and two Mongoloid and one Caucasoid cranical series from East Asia. Table 1 is the detailed list of the materials.

The cranial series from East India was used as that representing a Caucasoid population of less facial flattening. The Micronesians in Guam Island were considered Mongoloid following the suggestion advanced

Table 1. Cranial series examined.

\begin{tabular}{|c|c|c|c|c|}
\hline Cranial series & Provenance & Male & Female & Depository \\
\hline Ontario Iroquois & $\begin{array}{l}\text { Carton } \\
\text { Maurice } \\
\text { Kleinburg } \\
\text { Ossossane } \\
\text { Serpent Mounds }\end{array}$ & $\begin{array}{l}22 \\
13 \\
23 \\
17 \\
17\end{array}$ & $\begin{array}{r}15 \\
14 \\
36 \\
24 \\
2\end{array}$ & $\begin{array}{l}\text { University of Toronto } \\
\text { Ditto } \\
\text { Erindale College of University of } \\
\text { Toronto } \\
\text { Royal Ontario Museum, Toronto }\end{array}$ \\
\hline Canadian Eskimos & $\begin{array}{l}\text { District of Franklin } \\
\text { District of Mackenzie } \\
\text { District of Keewatin }\end{array}$ & $\begin{array}{l}18 \\
27 \\
22\end{array}$ & $\begin{array}{l}25 \\
27 \\
33\end{array}$ & $\begin{array}{l}\text { Archaeological Survey of Canada, } \\
\text { National Museum of Man, } \\
\text { Ottawa }\end{array}$ \\
\hline $\begin{array}{l}\text { Alaskan Eskimos } \\
\text { (Yupik) }\end{array}$ & $\begin{array}{l}\text { Lower Yukon } \\
\text { Golovin Bay } \\
\text { Norton Bay }\end{array}$ & $\begin{array}{r}22 \\
26 \\
2\end{array}$ & $\begin{array}{r}24 \\
26 \\
2\end{array}$ & $\begin{array}{l}\text { National Museum of Natural } \\
\text { History, Smithsonian Institu- } \\
\text { tion, Washington, D. C. }\end{array}$ \\
\hline $\begin{array}{l}\text { Alaskan Eskimos } \\
\text { (Inupik) }\end{array}$ & $\begin{array}{l}\text { Wales } \\
\text { Shishmarev } \\
\text { Point Hope }\end{array}$ & $\begin{array}{r}18 \\
7 \\
35\end{array}$ & $\begin{array}{r}14 \\
3 \\
21\end{array}$ & Ditto \\
\hline Aleuts & $\begin{array}{l}\text { Kagamil } \\
\text { Umnak } \\
\text { Shiprock }\end{array}$ & $\begin{array}{l}43 \\
15 \\
10\end{array}$ & $\begin{array}{r}38 \\
8 \\
3\end{array}$ & Ditto \\
\hline Mongols & Urga & 98 & 80 & Ditto \\
\hline East Indians & & 73 & 39 & $\begin{array}{l}\text { Queen's University at Kingston, } \\
\text { Canada }\end{array}$ \\
\hline Micronesians & Guam & 79 & 68 & B.P. Bishop Museum, Honolulu \\
\hline
\end{tabular}


by HASEBE (1938). Alaskan Eskimo crania were divided into two series according to dialects. The Inupik-speaking Eskimos occupied the upper area of Alaska and were in the same division as the Canadian Eskimos, while the Yupik-speaking Eskimos occupied the lower region of Alaska (OSWALT, 1967).

In addition to the metric data of these materials, those of the Ainu and Japanese crania were quoted from YAMAGUCHI (1973). Since the present author assisted him in measurements of facial flatness, the measuring techniques of both authors are completely consistent with each other. Thus, the data of YAMAGUCHI are comparable with those of the present author.

\section{Methods}

The same definitions of measurements and indices of flatness as described by YAMAGUCHI $(1973,1980)$ were used. The following brief descriptions of the definitions were quoted from YAMAGUCHI (1980).

1) Frontal index of flatness is the percentage of the nasion subtense to the chord between the frontomalaria orbitalia.

2) Simotic index is the percentage of the minimum subtense of the median ridge of the nasalia to the simotic chord, i. e., the minimum horizontal breadth of the nasalia.

3) Zygomaxillary index of flatness is the percentage of the subspinale subtense to the chord between the zygomaxillaria anteriora.

In the present study as in the report of YAMAGUCHI (1973), the subtenses were not measured directly with coordinate calipers, but obtained from three sides of a triangle measured by $0.1 \mathrm{~mm}$ with a pair of vernier calipers using the trigonometric formula as shown in Fig. 1.

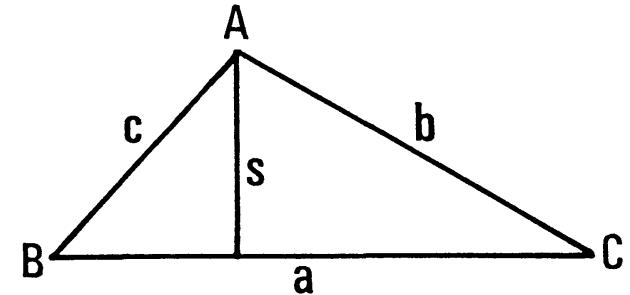

Fig. 1. Trigonometric formula. $\cos B=\left(a^{2}+c^{2}-b^{2}\right) / 2 a c$, $\sin B=\sqrt{1-\cos ^{2} B}$, Subtense $s=c \sin B$, Index $=\mathrm{s} / \mathrm{a} \times 100$.

During the investigation of the Eskimo series, crania with very narrow nasal bones were sometimes encountered. The simotic measurements were not taken for those crania whose nasalia were less than $4 \mathrm{~mm}$ in minimum width in order to secure an accuracy of these delicate measurements. Such crania amounted to 6.0 percent of male and 21.3 percent of female crania in the Canadian Eskimos, 6.8 percent of male and 18.4 percent of female crania in the Inupikspeaking Eskimos, and 8.3 percent of male and 15.4 percent of female crania in the Yupik-speaking Eskimos. Consequently, mean values of the simotic chord are considerably deviated from the true means in the Eskimo series. However, it should be noted here that the simotic index was scarcely influenced by such a situation, because no significant correlation is observed between the simotic chord and index $(\mathrm{r}=-0.16$ in the male Canadian Eskimo series).

Correlation of each index of flatness between sexes was measured by the SPEARMAN rank correlation coefficient (cf. SIEGEL, 1956).

The cranial series involved in the present study were compared with each other by means of a three-dimensional scatter diagram of the frontal, simotic, and zygomaxillary 
indices of flatness. In addition to these comparisons, PENROSE shape distances (cf. CONSTANDSE-WESTERMANN, 1972), based on the three sets of measurements and using the standard deviations of the Mongol series, were computed for all possible pairs among the cranial series under consideration. In order to examine positional relationships among all the cranial samples from the standpoint of facial flattening, the principal co-ordinates analysis developed by GowER (1966) was attempted on the basis of the matrix of PENROSE shape distances.

\section{Results of Measurements}

The results of frontal, simotic, and zygomaxillary measurements of flatness are given in Tables 2, 3 and 4, respectively. As described previously, the data of the Ainu and Japanese are quoted from YAMAGUCHI (1973).
Correlation of the index of flatness between the two sexes was measured by the SPEARMAN rank correlation coefficient (rs): $\mathrm{rs}=0.9636, \mathrm{n}=10, \mathrm{p}<0.01$ in the frontal index, $\mathrm{rs}=0.8970, \mathrm{n}=10, \mathrm{p}<0.01$ in the simotic index, and $r s=0.9152, n=10, p<0.01$ in the zygomaxillary index. A considerably high correlation coefficient is obtained in each of the three indices of flatness. In the frontal index, the mean of the East Indian series is the highest and that of the Mongol series the lowest for both sexes, while in the simotic index, the mean of the Canadian Eskimo series is the highest and that of the Micronesian series the lowest for both sexes. In zygomaxillary index, the mean of the Ontario Iroquois is the highest and that of the Mongols the lowest for both sexes. In the frontal region as well as in the zyg,omaxillary region, the mean indices of the

Table 2. Frontal measurements and index of flatness.

\begin{tabular}{|c|c|c|c|c|c|c|c|}
\hline \multirow{2}{*}{ Cranial series } & \multirow{2}{*}{ (n) } & \multicolumn{2}{|c|}{ Chord } & \multicolumn{2}{|c|}{ Subtense } & \multicolumn{2}{|c|}{ Index } \\
\hline & & $\mathrm{M}$ & $\mathrm{V}$ & M & $\mathrm{V}$ & $\mathrm{M}$ & $\mathrm{V}$ \\
\hline \multicolumn{8}{|l|}{ MALE } \\
\hline East Indians & $(73)$ & 95.7 & 17.24 & 18.3 & 4.75 & 19. 2 & 3.81 \\
\hline Micronesians & (77) & 99.7 & 11.75 & 16.0 & 4.45 & 16.0 & 4.02 \\
\hline Mongols & (97) & 100.7 & 18.21 & 14.7 & 4.94 & 14.5 & 3.82 \\
\hline Ontario Iroquois & (92) & 99.3 & 13.40 & 17.5 & 7.20 & 17.6 & 6.34 \\
\hline Aleuts & (66) & 100.5 & 13.19 & 15.2 & 4.60 & 15.1 & 3.89 \\
\hline Alaskan Eskimos (Yupik) & (48) & 100.2 & 5.74 & 14.9 & 3.22 & 14.9 & 3.28 \\
\hline Alaskan Eskimos (Inupik) & $(60)$ & 101.3 & 10.61 & 14.9 & 4.68 & 14.7 & 3.93 \\
\hline Canadian Eskimos & (67) & 101.0 & 11.82 & 15.8 & 6.97 & 15.7 & 6.13 \\
\hline Japanese* & (86) & 97.8 & 18.44 & 16.3 & 4.31 & 16.7 & 3.53 \\
\hline Ainu* & $(68)$ & 99.5 & 13.26 & 16.9 & 4.53 & 17.0 & 3.63 \\
\hline \multicolumn{8}{|l|}{ FEMALE } \\
\hline East Indians & $(39)$ & 91.0 & 10.62 & 17.5 & 5.25 & 19.2 & 5.07 \\
\hline Micronesians & (68) & 94.7 & 12.16 & 14.6 & 3.41 & 15.4 & 3.45 \\
\hline Mongols & $(79)$ & 94.8 & 12.90 & 13.2 & 4.35 & 13.9 & 4.23 \\
\hline Ontario Iroquois & (90) & 94.1 & 12.66 & 16.3 & 6.12 & 17.3 & 5.80 \\
\hline Aleuts & $(48)$ & 96.6 & 11.47 & 14.7 & 5.71 & 15.2 & 4. 94 \\
\hline Alaskan Eskimos (Yupik) & (51) & 95.5 & 10.75 & 14.6 & 5.31 & 15.2 & 4.79 \\
\hline Alaskan Eskimos (Inupik) & (38) & 96.6 & 11.17 & 13.8 & 3.09 & 14.2 & 3.13 \\
\hline Canadian Eskimos & (83) & 95.5 & 11.18 & 14.7 & 6.14 & 15.4 & 6.03 \\
\hline Japanese* & $(51)$ & 92.6 & 12.30 & 14.3 & 4.98 & 15.4 & 4.65 \\
\hline Ainu* & $(48)$ & 94.7 & 13.88 & 15.5 & 7.46 & 16.4 & 7.74 \\
\hline
\end{tabular}

* Yamaguchi (1973) 
Table 3. Simotic measurements and index of flatness.

\begin{tabular}{|c|c|c|c|c|c|c|c|}
\hline \multirow{2}{*}{ Cranial series } & \multirow{2}{*}{$(\mathrm{n})$} & \multicolumn{2}{|c|}{ Chord } & \multicolumn{2}{|c|}{ Subtense } & \multicolumn{2}{|c|}{ Index } \\
\hline & & M & $\mathrm{V}$ & $\mathrm{M}$ & $\mathrm{V}$ & $\mathrm{M}$ & $\mathrm{V}$ \\
\hline \multicolumn{8}{|l|}{ MALE } \\
\hline East Indians & $(72)$ & 8.8 & 2.27 & 4.1 & 0.91 & 47.1 & 103.64 \\
\hline Micronesians & (53) & 8.2 & 2.69 & 2.7 & 0.64 & 32.8 & 67.28 \\
\hline Mongols & (94) & 7.5 & 2.73 & 3.1 & 1.10 & 41.1 & 144.86 \\
\hline Ontario Iroquois & (80) & 9.0 & 2.29 & 3.8 & 0.69 & 42.7 & 115.62 \\
\hline Aleuts & (65) & 8.2 & 2.94 & 3.1 & 0.68 & 38.4 & 93.74 \\
\hline Alaskan Eskimos (Yupik) & (44) & 6.7 & 2.71 & 3.0 & 0.90 & 45.3 & 96.65 \\
\hline Alaskan Eskimos (Inupik) & (55) & 6.2 & 1.60 & 2.9 & 0.51 & 48.0 & 109.64 \\
\hline Canadian Eskimos & $(60)$ & 6.1 & 1.92 & 3.1 & 0.73 & 50.9 & 144.52 \\
\hline Japanese* & (86) & 7.2 & 3.65 & 2.7 & 0.95 & 38.7 & 163.38 \\
\hline Ainu* & (69) & 8.7 & 2.82 & 3.7 & 0.84 & 43.3 & 156.70 \\
\hline \multicolumn{8}{|l|}{ FEMALE } \\
\hline East Indians & $(38)$ & 8.7 & 2.33 & 3.3 & 0.63 & 38.6 & 64.32 \\
\hline Micronesians & (47) & 7.6 & 2.38 & 2.2 & 0.54 & 29.5 & 110.57 \\
\hline Mongols & (77) & 6.8 & 2.89 & 2.3 & 0.78 & 33.5 & 120.73 \\
\hline Ontario Iroquois & (77) & 8.5 & 2.63 & 3.3 & 0.72 & 40.0 & 114.76 \\
\hline Aleuts & (46) & 7.9 & 2.84 & 2.6 & 0.43 & 33.5 & 72.02 \\
\hline Alaskan Eskimos (Yupik) & $(44)$ & 6.6 & 2.81 & 2.5 & 0.56 & 38.7 & 108.10 \\
\hline Alaskan Eskimos (Inupik) & $(31)$ & 6.4 & 2.13 & 2.5 & 0.42 & 40.2 & 66.05 \\
\hline Canadian Eskimos & (56) & 6.0 & 1.56 & 2.4 & 0.25 & 40.8 & 96.77 \\
\hline Japanese* & $(50)$ & 7.4 & 1.97 & 2.2 & 0.59 & 30.6 & 102.84 \\
\hline Ainu* & (49) & 8.4 & 3.58 & 3.0 & 0.78 & 37.1 & 147.99 \\
\hline
\end{tabular}

* Y AMAGUCHI (1973)

Table 4. Zygomaxillary measurements and index of flatness.

\begin{tabular}{|c|c|c|c|c|c|c|c|}
\hline \multirow{2}{*}{ Cranial series } & \multirow{2}{*}{ (n) } & \multicolumn{2}{|c|}{ Chord } & \multicolumn{2}{|c|}{ Subtense } & \multicolumn{2}{|c|}{ Index } \\
\hline & & M & $\mathrm{V}$ & M & $\mathrm{V}$ & M & $\mathrm{V}$ \\
\hline \multicolumn{8}{|l|}{ MALE } \\
\hline East Indians & $(72)$ & 94.2 & 21.30 & 24.0 & 5.88 & 25.5 & 6.47 \\
\hline Micronesians & (54) & 102.7 & 23.66 & 22.8 & 4. 13 & 22.2 & 4.55 \\
\hline Mongols & (89) & 103.7 & 28.09 & 19.9 & 7.05 & 19.3 & 6.38 \\
\hline Ontario Iroquois & (38) & 102.0 & 22.28 & 27.4 & 6.80 & 26.9 & 6.50 \\
\hline Aleuts & (63) & 103.0 & 22.54 & 21.8 & 6.86 & 21.2 & 6.14 \\
\hline Alaskan Eskimos (Yupik) & (48) & 103.6 & 29.04 & 21.1 & 12.23 & 20.4 & 9.46 \\
\hline Alaskan Eskimos (Inupik) & $(58)$ & 104.1 & 25.49 & 22.7 & 5.88 & 21.9 & 6.08 \\
\hline Canadian Eskimos & (59) & 103.7 & 23.51 & 21.7 & 6.68 & 21.0 & 6.49 \\
\hline Japanese* & (83) & 97.9 & 26.92 & 23.6 & 8.37 & 24.1 & 8.97 \\
\hline Ainu* & (51) & 101.4 & 30.67 & 22.7 & 4.07 & 22.5 & 3.60 \\
\hline \multicolumn{8}{|l|}{ FEMALE } \\
\hline East Indians & (39) & 89.7 & 21.32 & 22.6 & 4.87 & 25.3 & 6.10 \\
\hline Micronesians & (43) & 95.6 & 16.74 & 20.9 & 3.41 & 21.9 & 3.91 \\
\hline Mongols & (72) & 96.3 & 19.77 & 18.2 & 6.42 & 18.9 & 6.42 \\
\hline Ontario Iroquois & (32) & 95.8 & 22.98 & 26.1 & 7.14 & 27.3 & 6.87 \\
\hline Aleuts & $(46)$ & 96.8 & 27.24 & 21.0 & 5.44 & 21.7 & 5.60 \\
\hline Alaskan Eskimos (Yupik) & $(48)$ & 97.6 & 19.00 & 20.1 & 5.01 & 20.6 & 4.64 \\
\hline Alaskan Eskimos (Inupik) & (35) & 98.5 & 15.44 & 21.8 & 5.86 & 22.1 & 7.59 \\
\hline Canadian Eskimos & (70) & 95.9 & 22.51 & 21.3 & 5.51 & 22.2 & 5.79 \\
\hline Japanese* & (49) & 93.6 & 25.08 & 22.3 & 5.18 & 23.8 & 5.81 \\
\hline Ainu* & $(21)$ & 95.6 & 29.65 & 22.2 & 7.53 & 23.2 & 6.72 \\
\hline
\end{tabular}

* YAMAGUCHI (1973) 
Mongols are lower (i. e., flatter) than any of the comparative series in both sexes.

\section{Comparison by Three-dimensional Diagram}

Following Fig. 2 in YAMAGUCHI (1973), a three-dimensional scatter diagram of the frontal, simotic, and zygomaxillary indices was drawn for each sex as shown in Figs. 2 and 3.
In both sexes all the Mongoloid series are clearly distinguished from the Caucasoid series (in this case the East Indian series) in the frontal index. With regard to the simotic index, considerably high mean values are observed in the three Eskimo series in males, and in the Ontario Iroquois series as well as the three Eskimo series in females. The Canadian Eskimos and Inupik-speaking

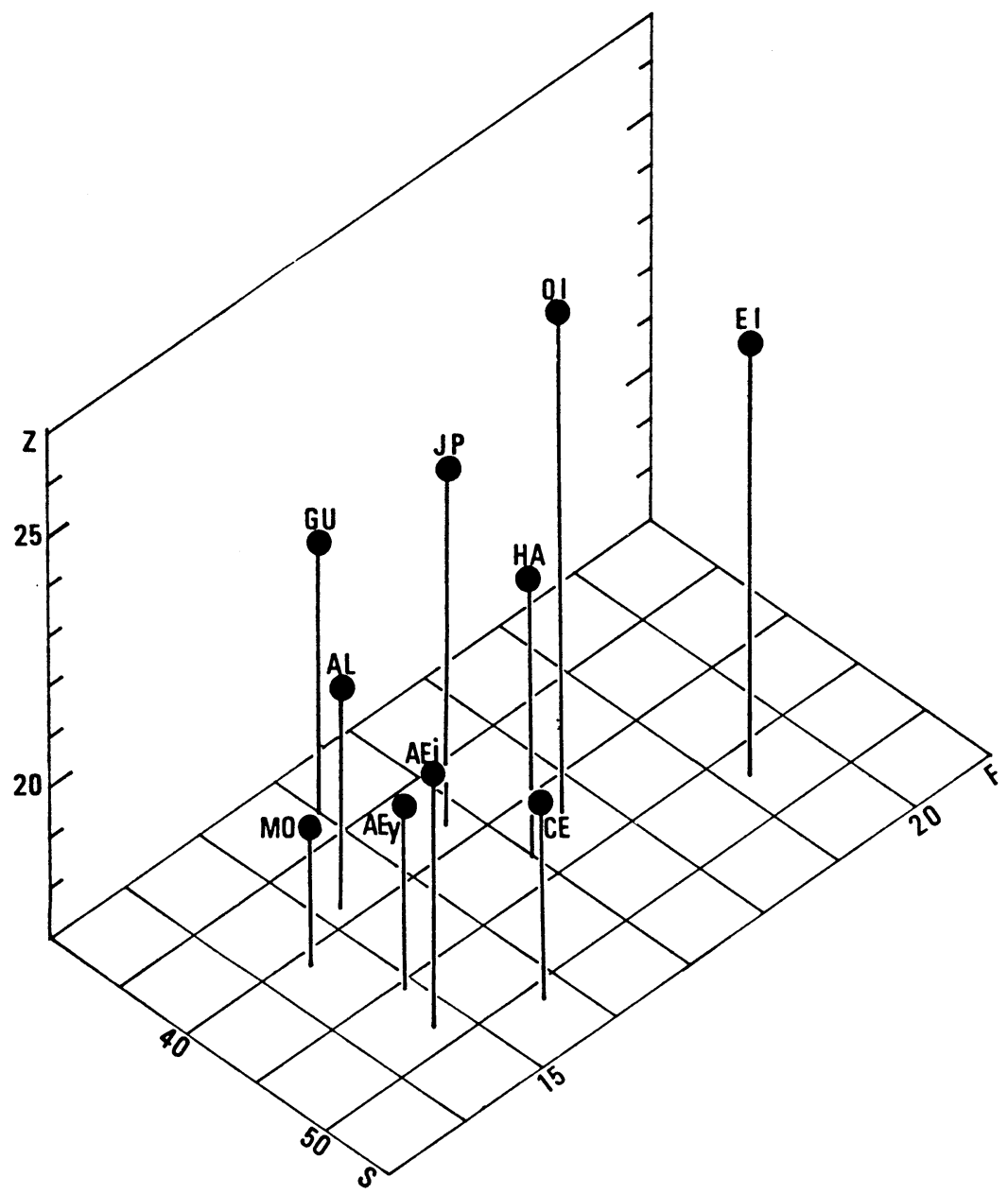

Fig. 2. A three-dimensional scatter diagram of the frontal (F), simotic (S), and zygomaxillary (Z) indices of flatness (Male). EI, East Indians; OI, Ontario Iroquois; HA, Hokkaido Ainu; JP, Japanese; GU, Micronesians (Guam); AL, Aleuts; AEy, Yupik Alaskan Eskimos; AEi, Inupik Alaskan Eskimos; CE, Canadian Eskimos; MO, Mongols. 


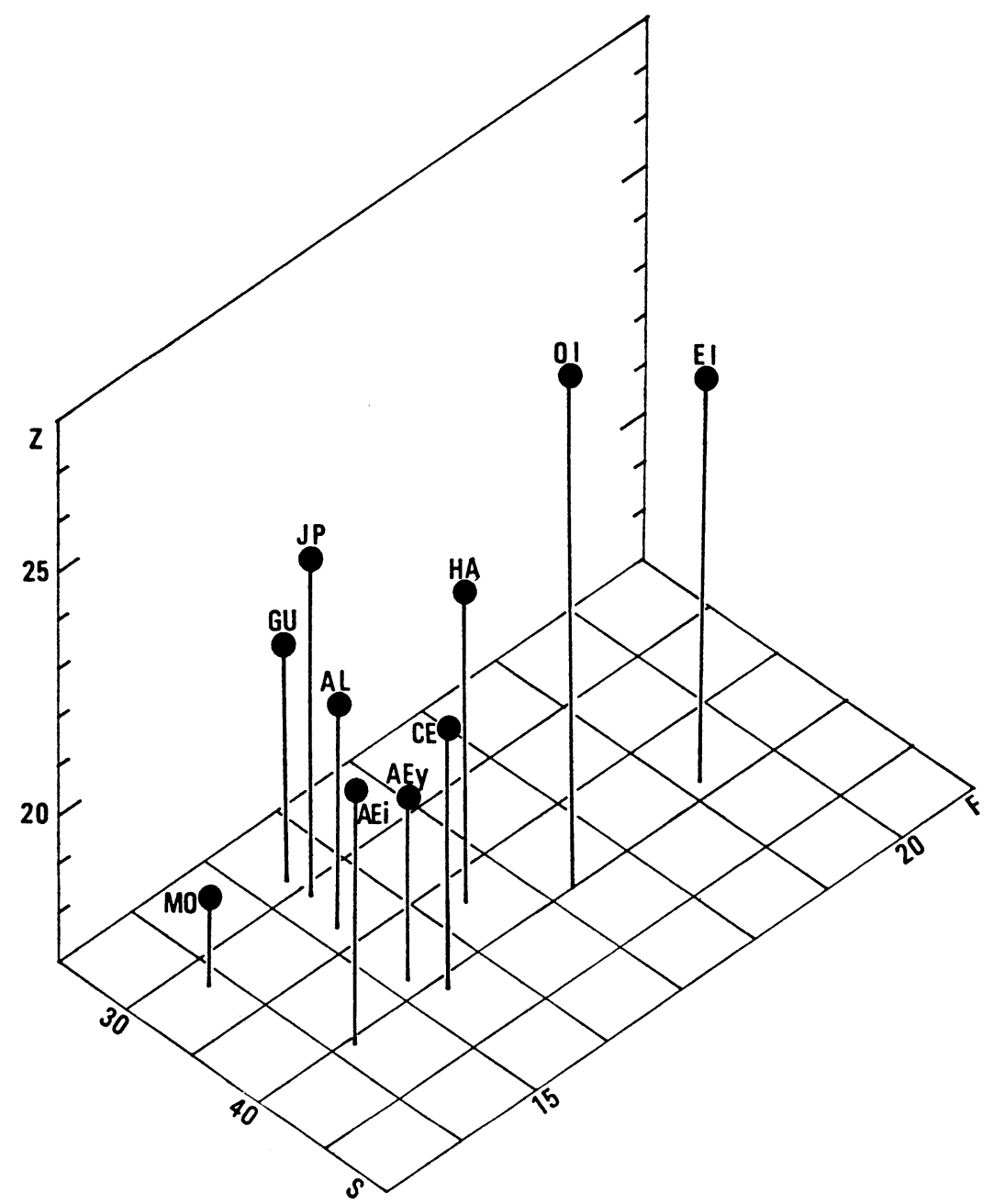

Fig. 3. A three-dimensional scatter diagram of the frontal (F), simotic (S), and zygomaxillary $(Z)$ indices of flatness (Female). See footnotes in Fig. 2 for abbreviations of population names.

Alaskan Eskimos exceed the Caucasoid series in the simotic index for both sexes. Concerning the zygomaxillary index, the means of the Ontario Iroquois and Japanese series are considerably high. The Ontario Iroquois series predominates over the Caucasoid series in the zygomaxillary index for both sexes. In all the indices of flatness, the means of the Mongols are extremely low for the two sexes.

\section{Penrose Shape Distance and Principal Co-ordinates Analysis}

On the basis of the frontal chord and subtense, the simotic chord and subtense, and the zygomaxillary chord and subtense, PENROSE shape distances were computed for all the pairs among the ten cranial series 
under analysis. The results for the male are shown in the upper right half of Table 5 and those for the female in the lower left half of the same Table.

Correlation of the distances between the two sexes measured by the SPEARMAN rank correlation coefficient (rs) is extremely high : $r s=0.9684, n=45, p<0.001$. The closest and the next closest distances are obtained between the Yupik-speaking Alaskan Eskimos and the Canadian Eskimos, and between the Inupik-speaking Alaskan Eskimos and the Canadian Eskimos, respectively, in the male series. In the female series, the closest distance is found between the Micronesians and Aleuts, and the next closest distance between the Ainu and Japanese. Among the Mongoloid series, the distance between the Mongols and Ontario. Iroquois is the farthest in both sexes, and that between the Canadian Eskimos and Ontario Iroquois is the next farthest in the male, while the distance between the Yupik-speaking Alaskan Eskimos and Ontario Iroquois is the next farthest in the female. These results are slightly different, especially in females, from those deduced from the three-dimensional diagrams (Figs. 2 and 3) which are constructed only by three indices of flatness.

On the basis of the matrix of PENROSE shape distances shown in Table 5 , the principal co-ordinates analyses were carried out, the results of which are illustrated two-dimensionally in Fig. 4. The first two principal components explain about 90 percent of the total variance in both sexes.

Positional relations of the male series coincide almost exactly with those of the female series. The East Indian series representing a Caucasoid population is located at a peripheral point in the lower right quadrant, whereas the Mongol series occu-

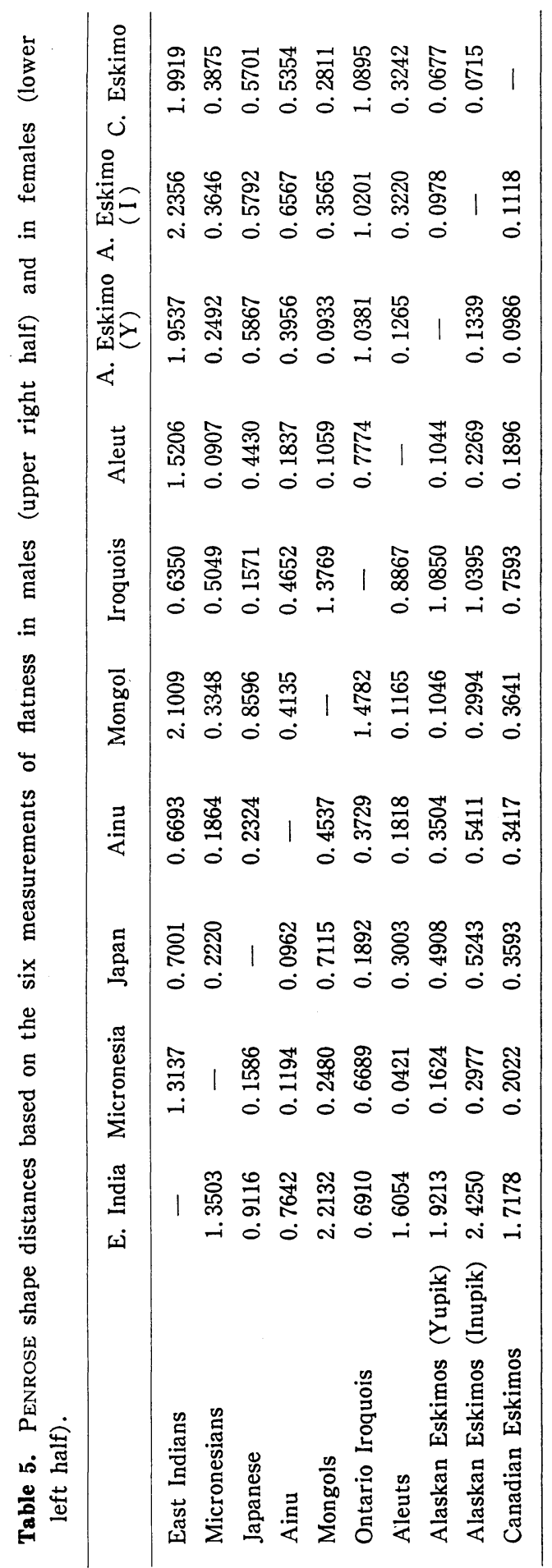



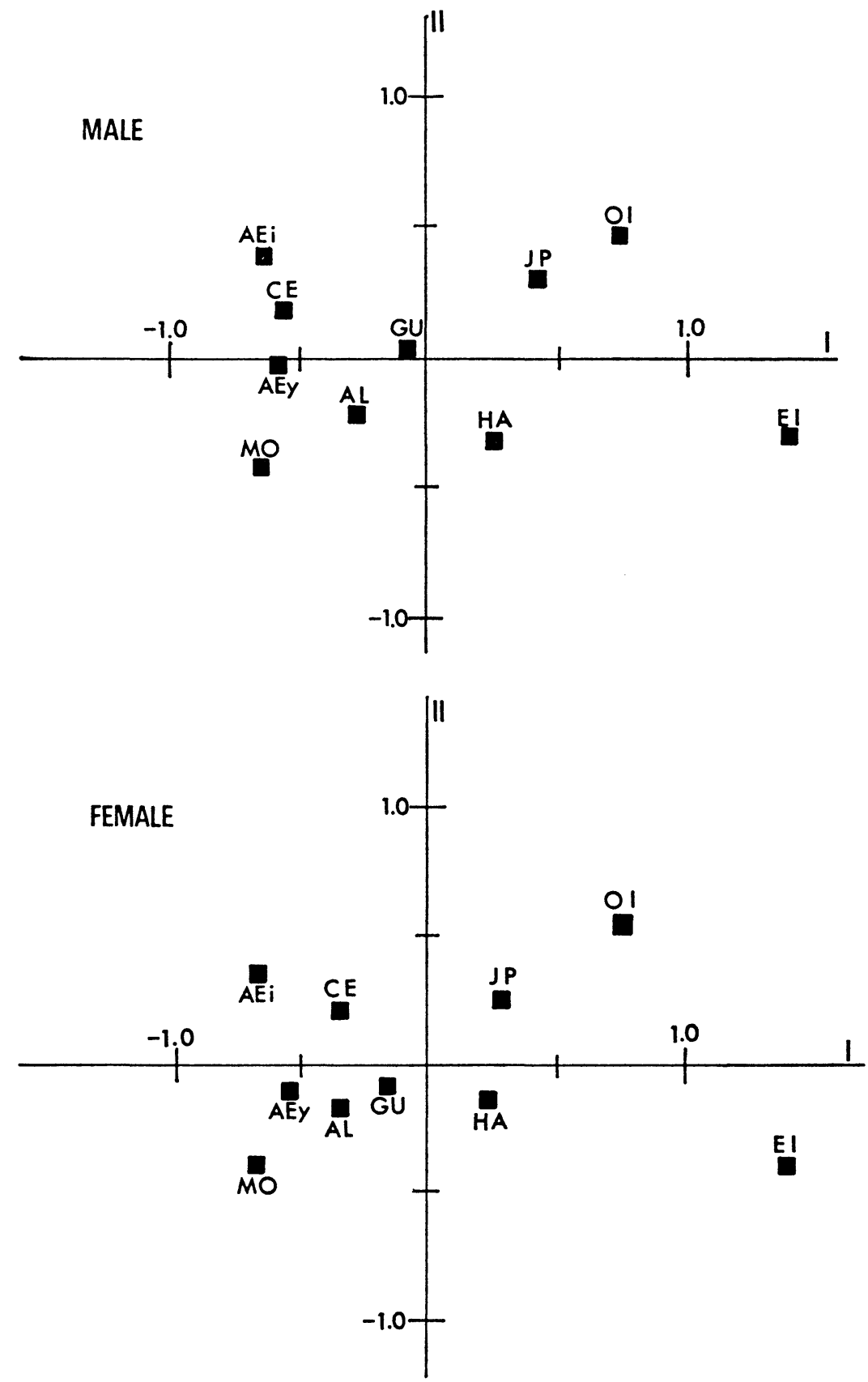

Fig. 4. Two-dimensional scatter diagrams of the ten cranial series constructed from the results of the principal co-ordinates analyses. EI, East Indians; OI, Ontario Iroquois; JP, Japanese; HA, Hokkaido Ainu; GU, Micronesians (Guam); AL, Aleuts; AEy, Yupik Alaskan Eskimos; AEi, Inupik Alaskan Eskimos; CE, Canadian Eskimos; MO, Mongols. 
pies the opposite side in the lower left quadrant, although it lies within the range of variation of Northern Mongoloid groupings. The Canadian Eskimo and Inupikspeaking Alaskan Eskimo series are close to each other and situated in the upper left quadrant. The Yupik-speaking Alaskan Eskimo is rather close to the Aleut series and both series are located in the lower left quadrant. The Japanese and Ontario Iroquois series are relatively close to each other and situated in the upper right quadrant. The position of the Ontario Iroquois appears to be on the periphery range of variation in the Mongoloid series. The Ainu, together with the East Indians, is located in the lower right quadrant, but it is far closer to the area of Mongoloid grougings. The position of the Micronesians is close to the center of the co-ordinates and approximately intermediate between the Japanese and Ontario Iroquois cluster and the Northern Mongoloid cluster.

\section{Discussion}

Probably, the present study is the first to clearly indicate that the frontal, simotic, and zygomaxillary indices of flatness are highly correlated between the two sexes, though such trends can be inferred from Figs. 1 and 2 in Woo and Morant (1934). The high correlation between the two sexes is also observed in PENROSE shape distances based on the three sets of facial flatness measurements. Probably due to this strong correlation between sexes, the positional relations of the cranial series shown in Fig. 4 are almost exactly coincident between the two sexes.

Figs. 2 and 3 show that the frontal index of flatness clearly discriminates the East Indians from the Mongoloid series as a whole. Though Woo and MoRANT (1934) pointed out that the frontal and simotic indices were the two most suggestive indices for the discrimination of racial varieties, the range of variation of the simotic index is considerably wide in the present Mongoloid series. The mean simotic indices of the Canadian Eskimos and Inupik-speaking Alaskan Eskimos exceed that of the East Indians in both sexes. The zygomaxillary index of flatness also clearly distinguishes the East Indians from the Mongoloid series, with the exception of the Ontario Iroquois series whose mean zygomaxillary index is larger than that of the East Indian series in both sexes. From these facts, it is inferred that the combination of the frontal and zygomaxillary indices is more effective than the combination of the frontal and simotic indices in differentiating the Mongoloid and the Caucasoid groupings.

Both in the three-dimensional diagrams of the three indices of flatness (Figs. 2 and 3) and in the principal co-ordinates analyses (Fig. 4), the position of the Ainu is not intermediate between the Mongoloid and the Caucasoid series, but is far closer to the Mongoloid groupings. This result is slightly different from that reported by YAMAGUCHI (1973). The Ainu is apparently included within the range of variation of the Mongoloid series with regard to facial flattening.

In Fig. 4 showing the results of the principal co-ordinates analyses, the Japanese and Ontario Iroquois are close to each other, located in the upper right quadrant. The positional relations of the two series are considerably different between the twodimensional diagrams based on the principal co-ordinates analyses (Fig. 4) and the threedimesional diagrams of the three indices of flatness (Figs. 2 and 3). The close positional 
relationship between the Japanese and Ontario Iroquois series shown in Fig. 4 appears to be the result mainly due to their less flat zygomaxillary region. By a discriminant analysis of 30 population samples on the basis of eight cranial measurements, YAMAGUCHI (1981) obtained the result that the morphological distance between the Japanese and Ontario Iroquois is considerably small. Therefore, it is not unreasonable to postulate the intimate relationship between the two population samples in regard to their facial flatness.

As seen also in Fig. 4, the Inupik-speaking, Alaskan Eskimo is slightly closer to the Canadian Eskimo than to the Yupik-speaking Alaskan Eskimo. The former two series are located in the upper left quadrant, whereas the latter series is situated in the lower left quadrant. These positional relations among the three Eskimo series are consistent with the geographic and linguistic relations of these Eskimo series. In this respect, the results of the principal co-ordinates analyses appear to be more reasonable than those of the three-dimensional diagrams based only on the three indices of flatness. The fact that the Canadian Eskimos and the Inupikspeaking Alaskan Eskimos are located in the upper left quadrant and form a cluster separable from other Northern Mongoloid series in Fig. 4 may be interpreted as the extreme horizontal protruding of their nasal bones.

In general, the Eskimo's face is characterized by the extremely flat frontal and zygomaxillary regions and pronounced nasal bones. The face of a young Inuit lady shown in Fig. 5 appears to represent the features characteristic of the Eskimos. High mean values of the simotic index in the Eskimos have already been presented by

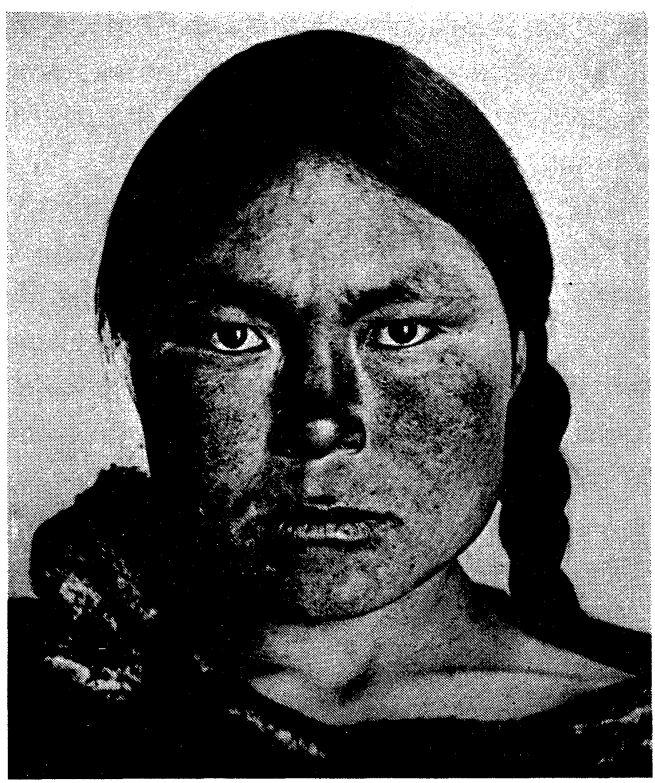

Fig. 5. A photograph of a young Inuit lady taken by Mr. A. A. Chesterfield at the east coast of Hudson Bay between 1902 and 1904 (JAMES, 1983). Courtesy of Queen's University Archives, and Mr. D. E. MACNAIR, the nephew of the Inuit lady.

Woo and Morant (1934), Debets (1951) and AlExSEEV (1979a). The mean simotic indices of the three Eskimo series are almost equal to, or even higher than that of the Caucasoid series in the present study. However, since the mean values of the simotic chord of the Eskimos are lower than any of the comparative series as seen in Table 3 , the morphology of the nasal bones must be considerably different between the Eskimo and the Caucasoid series.

According to HyLANDER (1972), the Eskimo crania are characterized by reduced nasal bones and enlarged frontal processes of the maxillae. Further, he stated "it appears that nasal bone reduction among the Eskimos is actually correlated with an enlargement of the frontal processes of the maxillae, 
and this enlargement is viewed as an adaptation to transfer large biting forces from the anterior part of the face to the neurocranium."

The increased facial flatness of the Mongoloid people has been traditionally explained by the cold adaptation theory advanced by Coon et al. (1950). However, it appears that the reduced but prominent-so-called "pinched"-nasal bones of the Eskimo crania do not intimately correlate to cold adaptation. ENDO (1970) demonstrated experimentally that during anterior biting, the frontal processes of the maxillae are under considerable amounts of compressive stress, while the nasal bones are only slightly stressed. Referring to the ENDO's report, HYLANDER (1972) concluded that nasal bone reduction is coupled with enlargement of the frontal processes of the maxillae which is viewed as an adaptation to effectively dissipate the large biting forces in the anterior part of the Eskimo face. Not only the reduction, but also the prominency of the nasal bones of the Eskimo crania may be explained from the biomechanical standpoint. At any rate, however, further research, whether morphological or experimental, will be necessary for a precise interpretation of the "pinched" nasal bones of the Eskimo crania.

\section{Acknowledgment}

I wish to express my gratitude to Dr. N.S. OSSENBERG of Queen's University for helpful advice on materials. I am deeply indebted to the following persons for permission to examine cranial materials: Dr. S. NAGATA, University of Toronto; Dr. F. J. MELBYE, Erindale College. University of Toronto; Ms. P. DANiels, Royal Ontario Museum; Dr. J. S. Cybulski, Archaeological Survey of Canada, National Museum of Man; Dr.
J. L. ANGEL, National Museum of Natural History, Smithsonian Institution; Dr. M. G. JONEJA, Queen's University ; Dr. Y. SHINOTO, B. P. Bishop Museum. Thanks are also given to Mr. M. UMEDA and Mrs. C. NAKano of Sapporo Medical College for technical assistance. The investigation of the Micronesian crania kept at B. P. Bishop Museum was financially supported by the Grant for Overseas Scientific Research in 1984 from the Japanese Ministry of Education (Director, Dr. K. Hanihara).

\section{抄録}

東アジアおよび北アメリカ諸集団頭骨

の顔面平坦度について

$$
\text { 百々幸雄 }
$$

北アメリカ由来のモンゴロイド 5 集団と東アジア由 来のモンゴロイド 2 集団およびューカソイド1集団の頭 骨について，3組の顔面平坦度計測をおこなった。 ンゴロイド集団は, オンタリオ・イロコワ, カナダェ スキモー, イヌピック系とユピック系のアラスカエス キモー, アレウト，モンゴル人, グアム島のミクロネ シフ人で，コーカソイド集団は東インド人である. 調 査した資料の詳細は表 1 に示した。このほかに，YAMAGUCHI (1973) が報告したアイヌと日本人の計測デ ータを比較に用いた。

計測法は YAMAGUCHI $(1973 ， 1980)$ にしたがい, 前頭部, 鼻骨拉よび頓上顎部の平坦度計測がおこなわ れた，その結果は，それぞれ表 $2 ， 3 ， 4$ に示すとお りである. 前頭, 鼻骨, 煩上顎の各平坦示数の男女間 の相関をSPEARMAN の順位相関係数で計るとかなり 高い值が得られ，いられも $1 \%$ 水準で有意であった。

3 つの平坦示数の 3 次元分布図（図 2 と図 3 ）を描 くと，鼻骨平坦示数は変異の幅が大きすぎるので，前 頭平坦示数と頓上買平坦示数の組合わせが, モンゴロ イドとコーカソイドを分類するのにより有効であると 思われた. モンゴル人は男女とも，いづれの示数も小 さく，顔面がとくに平坦であることがうかがわれた.

平坦示数のみの比較では不十分と思われたので，前 頭部, 鼻骨および頓上顎部の 6 項目の計測値を用いて 
PENROSE の形態距離を求めたが，その結果は表 5 に 示した. 形態距離も男女間の相関が高く, SPEARMAN の順位相関係数は 0.97 で, $0.1 \%$ の水準で有意であっ た. 距離マトリックスを類似度マトリックスに変換し て，主座標分析をほどこしたが，その結果を 2 次元に 展開したのが図 4 である，各集団の位置関係は男女間 でほぼ完全に一致している．また，エスキモー3 集団 の位置関係も, 地理的・言語学的関係とほぼ一致して いる. 日本人とオンタリオ・イロコワが比較的近い位 直を占めているが，この関係は山口（1981）が頭骨計 測値の判別分析ですでに指摘したところである.

エスキモーの鼻骨平坦示数は東インド人のそれと同

等か, それをやや上まわる值となっているが，これは エスキモーの鼻骨が幅狭くしかも突出している（いわ ゆる “pinched”) ためである. エスキモーの“pinched nasalia”については, HYLANDER (1972) が結論した ように, 生物力学的観点から説明するのが妥当かと思 われるが; より厳密な解釈にはなお一層の研究が必要 であろら・

\section{References}

Alexseev, V.P., 1979a: Anthropometry of Siberian peoples. In: LAughlin, W.S. and A.B. HARPER ed. The first Americans: origins, affinities, and adaptations. Gustav Fischer, Stuttgart. pp. 57-90.

Alexseyev, V.P., 1979b: On Eskimo origins. Current Anthrop., 20 : 158-164.

Constandse-Westermann, T.S., 1972: Coefficients of biological distance. Anthrop. publications, Oosterhout, the Netherlands.

Coon, C.S., S. M. GARN and J. B. Birdsell, 1950 : Races: a study of the problems of race formation in man. Charles C. Thomas, Springfield.

Debets, G.F., 1951 : Antropologicheskie issledovaniya v Kamchatskoi Oblasti. Trudy Inst. Etnografii, n.s. 17 : 1-263.

ENDO, B., 1970: Analysis of stresses around the orbit due to masseter and temporalis muscles respectively. J. Anthrop. Soc. Nippon, 78: 251-
266.

Gower, J.C., 1966: Some distance properties of latent root and vector methods used in multivariate analysis. Biometrika, 53 : 325-338.

HAsebe, K., 1938: The natives of the South Sea Archipelagos. Jinruigaku Senshigaku Koza, I. Yuzankaku, Tokyo. pp. 1-38. (In Japanese).

[長谷部言人, 1938 : 南洋群島人. 人類学・先史学講 座, 第 1 巻. 雄山閣, 東京. pp. 1-38.]

Heathcote, G. M., 1981: On Alekseyev on Eskimo origins. Current Anthrop., 22 : 582-584. Hylander, W.L., 1972: The adaptive significance of Eskimo craniofacial morphology. $\mathrm{Ph}$. D. thesis of the University of Chicago.

James, W.C., 1983: A. A. Chesterfield Ungava portraits 1902-04. Agnes Etherington Art Center, Queen's Univ., Kingston, Ontario.

Oschinsky, L., 1962: Facial flatness and cheekbone morphology in Arctic Mongoloids. Anthropologica, n.s. $4: 349-377$.

Oschinsky, L., 1964 : The most ancient Eskimos. Univ. of Ottawa, Ottawa.

Oswalt, W.H., 1967: Alaskan Eskimos. Chandler, San Francisco.

SIEGEL, S., 1956: Nonparametric statistics for the behavioral sciences. McGraw-Hill, New York.

Woo, T.L. and G. M. Morant, 1934: A biometric study of the "flatness" of the facial skeleton in man. Biometrika, $26: 196-250$.

YAMAGUCHI, B., 1973: Facial flatness measurements of the Ainu and Japanese crania. Bull. Natn. Sci. Mus. Tokyo, 16 : 161-171.

YAMAGUCHI, B., 1980: A study on the facial flatness of the Jomon crania. Bull. Natn. Sci. Mus., Tokyo, Ser. D, 6: 21-28.

YAMAGUCHI, B., 1981 : Prehistoric human skeletal remains in Hokkaido. In: OGATA, T. ed. Jinruigaku-koza 5. Nipponjin I. Yuzankaku, Tokyo. pp. 137-156. (In Japanese).

[山口 敏, 1981 : 北海道の古人骨. 小片保 (編著), 人類学講座 5 . 日本人 I. 雄山閣, 東京. pp. 137156.]

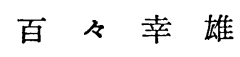

Yukio DoDo
札幌医科大学解剖学教室

厂060 札幌市中央区南 1 条西 17 丁目

Department of Anatomy, Sapporo Medical College South-1, West-17, Chuo-ku, Sapporo 060 Japan 